University, "Political Ambition"

Theresa Marchant-Shapiro, Union College, "With a Finger to the Wind: Primary Candidates' Strategic Use of Issues"

Jeffrey Ian Ross, University of Lethbridge, "The Other Side of the Big Six: Politics and Control of Police Violence in Major American Cities"

Richard Stahler-Sholk, Pitzer College, "Debt, Adjustment, and Organized Labor: Problems of Democratization in Nicaragua"

Yuan Ting, Oakland University, "An Analysis of the Impact of AFDC Benefit Levels on the Interstate Migration of AFDC Recipients"

Daniel Wirls, University of California-Santa Cruz, "Explaining Senate Elections: The Problems of Mixed-Party Delegations"

Voytek Zubek, University of Alabama-Birmingham, "The Crystallization of Poland's Party System"

\section{Ralph Bunche Summer Institute}

Twenty-five juniors who have demonstrated interest and potential in the field of political science participated in the seventh annual Ralph Bunche APSA Summer Institute in Political Science for Black Students, held June 8-July 18 in Atlanta, Georgia.

The Institute was conducted by a consortium consisting of Spelman College, Morehouse College, Georgia State University, Clark-Atlanta University and Emory University. Lois Moreland of Spelman College was director of the 1992 institute. Roger Miller of Georgia State, Eleanor Main and Micheal Giles of Emory University, Tobe Johnson of Morehouse College, and William Boone of Clark-Atlanta University were coordinators of their respective campuses.

The students selected as institute participants came from diverse universities and colleges from 18 different states and the District of Columbia.

Craig M. Brodhead, State University of New York

Ernecia S. Coles, University of Virginia
Amy D. Donaldson, University of Alabama

Melissa N. Doss, Trenton State College

Jared K. Ellison, Tuskegee University

James R. Freeman, University of California, Santa Barbara

David A. Glass, Lock Haven University

Erika L. Gordon, Spelman College

Thomasine Gore, St. Augustine College

Julian Guillroy, Southern University

Bridget L. Hardaway, West Georgia College

Ayanna B. Hobbs, Drake University

Lisa M. Howard, Bethune-Cookman College

Shawtrice L. Jackson, Cornell

University

Robert James, Marquette University

Adrian M. Lewis, Tennessee State University

Eric P. Martin, Baldwin-Wallace College

Eric J. Narcisse, University of Texas

Enette Nelson, University of South Florida

John T. O'Neal, University of North Carolina, Chapel Hill

Nancy M. Pretto, Howard University

Tamara T. Saduddin-Singh, University of South Carolina

Kimberly M. Smith, Tufts University

Fred Shotlow, Jr., Northeastern University

Tamelyn N. Tucker, Hampton University

The six-week program consisted of two graduate level courses taught on two of the campuses of the member institutions. Each participant also completed a research project integrating the two courses. The project involved original, empirical research. Academic credit for successful completion of the courses was awarded by Spelman College.

Students also participated in a series of lectures and workshops. These included: sessions where prominent political scientists discussed their work, a workshop that focused on the Graduate Record Exam, and sessions with recruiters of graduate programs from leading institutions.

\section{The American Political Science Association Policy and Procedures for Permission to Reprint Articles, * 1992}

The author of the material to be reprinted is free to give or deny permission, or to impose conditions, fees or a share of royalties. In all cases, the author's permission must be requested. Reprinting material without permission and/or without full attribution is a violation of the Association's code of professional ethics.

The Association, upon receiving a request to reprint an article, informs the requester that a detailed response will be forthcoming after the Association contacts the author or authors. At the same time, the publisher is asked for information about the intended publication, its audience, and whether or not the article will be edited. Upon receipt of this information, the APSA notifies the author of the request, conveys the information provided by the publisher, and asks the author to complete a form, noting whether or not permission is given and the conditions under which it will be given.

A response is then made to the person requesting permission to reprint, informing him/her of the author's wishes. A normal fee specified by authors is $\$ 200$. (That fee is often shared when more than one author has written an article.) The Association requests a fee of $\$ 100$ for each article or major portion thereof, for commercial use. These fees are waived for an author seeking permission to reprint his/her own article(s).

The Association also requires that a request be submitted when a publisher seeks to reprint a table or a figure from an article or any segment of an article that is 1,000 words or

*This statement pertains to material to be reprinted in books and bound volumes and not to material to be copied or reproduced for class use. The APSA has a separate policy regarding granting permission to copy articles for classroom use. 